\title{
COMPLETE EXCISION OF URACHAL CYST BY LAPAROSCOPIC MEANS: A NEW APPROACH TO AN UNCOMMON DISORDER.
}

\author{
Octavio A. Castillo?,2, Gonzalo Vitaglianol, Ruben Olivares' and Rafael Sanchez-Salas'.
}

Santa Maria' and Department of Urology. School of Medicine, Universidad de Chile². Santiago de Chile.

\begin{abstract}
Summary.- OBJETIVE: Anomalies of the urachal remnant are rare. Urachal cysts are usually asymptomatic, however, when they become infected, they can mimic a wide variety of intra-abdominal pathologies. We present two patients in which an urachal cyst was found.
\end{abstract}

METHODS: Two male patients 25 and 38 years old respectively underwent laparoscopic resection of an urachal remnant. In one of the cases the urachal remnant was complicated by infection. Opportune clinical and radiologic diagnose was made in both cases and complete excision of the urachal remnant was carried out by laparoscopic means.

RESULTS: The procedures were performed without complications and follow up showed excellent results. Both patients presented very short convalescence with rapid recovery.

Octavio A. Castillo

Department of Urology

0
0
$\frac{1}{0}$
0
0
0
0
0
0
0
0
0

Clínica Santa María

Avda Santa María 0500

7530234 Providencia

Santiago de Chile

octaviocastillo@vtr.net

Acepted for publication:
CONCLUSIONS: The treatment of choice for urachal pathology is the complete excision of the complicated lesion. For this matter laparoscopic surgery assures surgical results comparable to conventional surgery adding the advantages of a minimally invasive approach.

Keywords: Urachal cyst. Urachus. Cyst. Laparoscopy.

Resumen.- Las anomalías del remanente de uraco son raras. Los quistes de uraco son generalmente asintomáticos; sin embargo, cuando se infectan, pueden imitar una amplia variedad de patologías intraabdominales. Presentamos dos pacientes con quiste de uraco.

MÉTODOS: Dos pacientes varones de 25 y 38 años, respectivamente, fueron sometidos a resección laparoscópica de remanentes de uraco. En uno de los casos el remanente de uraco se había complicado con infección. En ambos casos se hizo el diagnóstico clínico y radiológico adecuado y se llevó a cabo escisión completa del remanente de uraco por vía laparoscópica.

RESULTADOS: Las operaciones se realizaron sin complicaciones y el seguimiento mostró unos resultados excelentes. Ambos pacientes tuvieron una convalecencia muy corta, con una rápida recuperación.

CONCLUSIONES: El tratamiento de elección de la patología de uraco es la escisión completa de la lesión complicada. La cirugía laparoscópica asegura unos resultados quirúrgicos comparables con la cirugía convencional, añadiendo las ventajas del abordaje mínimamente invasivo. 
Palabras clave: Quiste de uraco. Uraco. Quiste. Laparoscopia.

\section{INTRODUCTION}

The urachus is the embryological remnant of the allantois, which originally communicates with the vertex vesicae (the apex of the bladder) to the umbilicus. During embryonic development the urachus starts to obliterate in the $10 \mathrm{~mm}$ embryo, coming to a complete fusion in the $16 \mathrm{~mm}$ embryo; in this phase, it separates from the umbilicus and then completely obliterates, shortly after birth, giving rise to the median umbilical ligament (1).

Urachal defects are rare with urachal cysts being the most common anomaly occurring in approximately $1 / 5,000$ births. Usually urachal cysts are asymptomatic and manifest themselves only when infected.

The traditional approach for removing urachal remnant and for the treatment of complicated urachal cysts has been open surgery. This intervention is recommended over drainage of the abscess cavity and antibiotic therapy due to the risk of recurrence and the potential for malignant change of the urachal remnant $(2,3)$. However, open surgery is associated with increased morbidity and longer convalescence. Herein, we report our experience in the laparoscopic management of urachal anomalies.

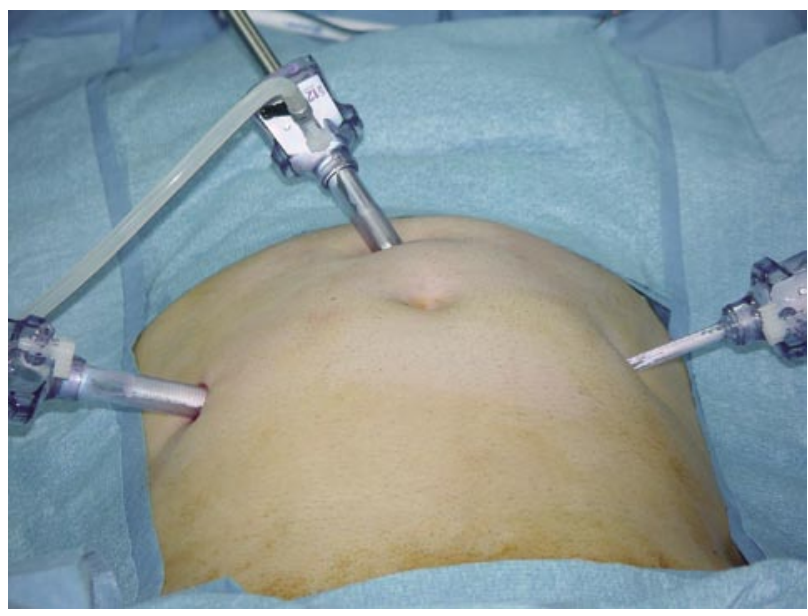

FIGURE 1. Three trocar approach.

\section{MATERIAL AND METHODS}

Two patients underwent laparoscopic surgery for urachal pathology at our institution.

Case № 1: A twenty-five year old male, with previous history of myelomeningocele, surgically treated at 16 years of age, paraplegic, presented with fever and a lower abdominal mass. Patient had a diagnosis of neurogenic bladder in clean intermittent catheterism program. An abdominal ultrasound revealed an infraumbilical cystic mass in continuity with the bladder. The CT-Scan confirmed the presence of a cystic mass with heterogeneous content in continuity with the bladder dome. A complicated urachal cyst was suspected. Laparoscopic abdominal exploration was performed.

Case № 2: A thirty-eight year old male with no past medical history was seen for an incidental cystic lesion of $1.9 \mathrm{~cm}$ found on a routine abdominal ultrasound. An abdominal CT-scan revealed a calcified $2 \mathrm{~cm}$ nodular image on the bladder dome (Figure 3). The patient requested surgery.

\section{Surgical Technique}

The patient is placed in a modified lithotomy position with the legs apart. The surgeon stands on the left side of the patient. An assistant seated in between the patient legs simultaneously performs a cystoscopy. Surgeon simultaneously views both the laparoscopic and endoscopic fields. A three port technique is used. A $10 \mathrm{~mm}$ trocar is placed supra-umbilical for the $0^{\circ}$ laparoscope and two paraumbilical trocars, $10 \mathrm{~mm}$ on the right and a $5 \mathrm{~mm}$ on the left are respectively placed (Figure 1). Using the combined cystoscopic and laparoscopic approach, partial cystectomy is performed. The bladder cuff is excised in one piece with the urachus and umbilicus. Surgical margins are controlled with cystoscopy. The bladder is sutured transversally with a continuous intracorporeal polyglactine 3-0 suture.

\section{RESULTS}

On the first case, surgery lasted 90 minutes with no bleeding. The mass was extracted in a plastic bag through an umbilical incision (Figure 2). Histologic analysis revealed a $12 \times 6 \mathrm{~cm}$ mass which included bladder wall and an infected urachal cyst. The patient was discharged on post operative day 5 and the urethral catheter was withdrawn on day 7 . During the 72 months of follow up no recurrence was evident. 


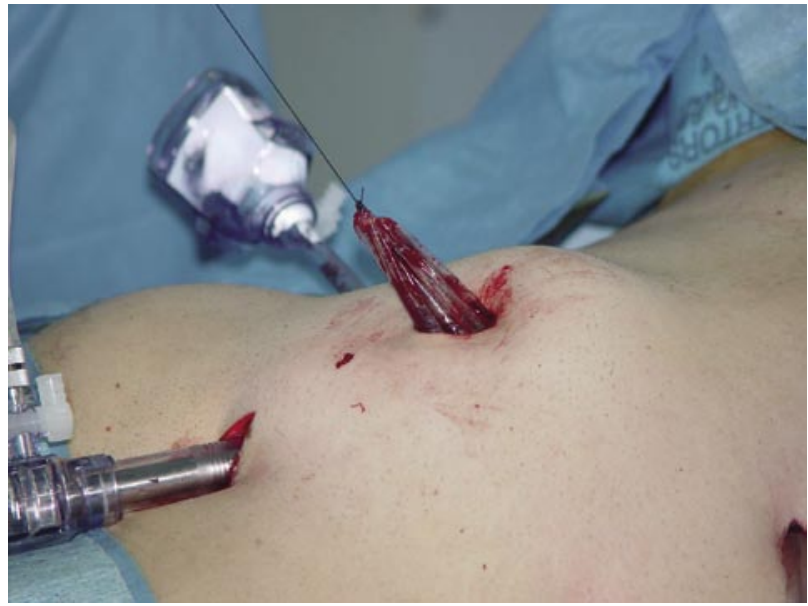

FIGURE 2. Mass extracted in a plastic bag through the umbilical incision.

On the second case, OR time was 75 minutes and the patient was discharged from hospital on post operative day 5 without an indwelling urinary catheter. Final pathological evaluation confirmed the presence of a non-complicated partially calcified urachal cyst (Figure 4). There was no recurrence during an 8 month follow-up.

\section{DISCUSSION}

The urachus is the embryologic remnant of the allantois and is found among the medial umbilical ligaments which in turn are remnants of the fetal umbilical arteries.

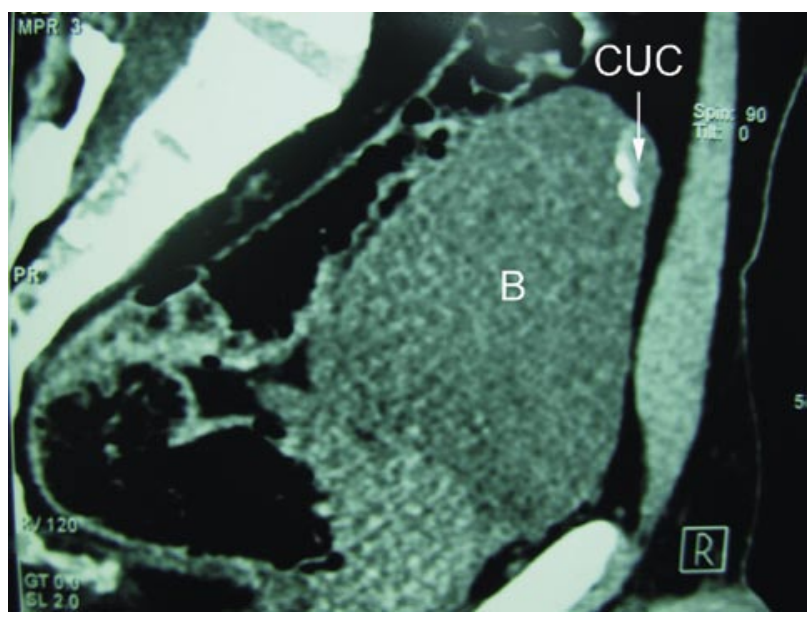

FIGURE 3. An abdominal CT-scan reveals a calcified 2 $\mathrm{cm}$ nodular image on the bladder dome. CUC-calcified urachal cyst. B- bladder.
The allantois appears for the first time in the fetus around day 16; as the bladder grows and descends to the pelvis, the distal allantois obliterates. During the fourth and fifth months of gestation the fetus stretches and grows the distance between the vertex vesicae and the navel. The urachus or medial ligament turns into a fibrous cord originating in the vesical apex and extending to the navel, oscillating from 3 to $10 \mathrm{~cm}$ in length and from 8 to $10 \mathrm{~mm}$ in diameter (1).

The incapacity for obliteration of the urachus is infrequent, but when it appears it is usually in infan$c y$, clinically important anomalies have an incidence of 2 in 300,000 births (4).

Urachal anomalies can be divided into congenital and acquired (5). Congenital anomalies manifest themselves as loss of urine through the navel and cause a persistence of the permeability of the urachus or the bladder's impossibility to descend to the pelvis. The acquired anomalies appear when the urachus closes after birth and reopens later due to pathological factors.

Urachal cysts arise out of desquamation and degeneration of the urachal epithelium. The small connection existing between the urachus and the bladder can clear the way for a bacterial infection which becomes manifest with fever, abdominal pain and may even resemble an acute abdomen, a palpable abdominal mass or a urinary infection (6). The complications of infected urachal cysts include rupture in the peritoneal cavity leading to an inflammatory involvement of the adjacent intestine and necrotizing

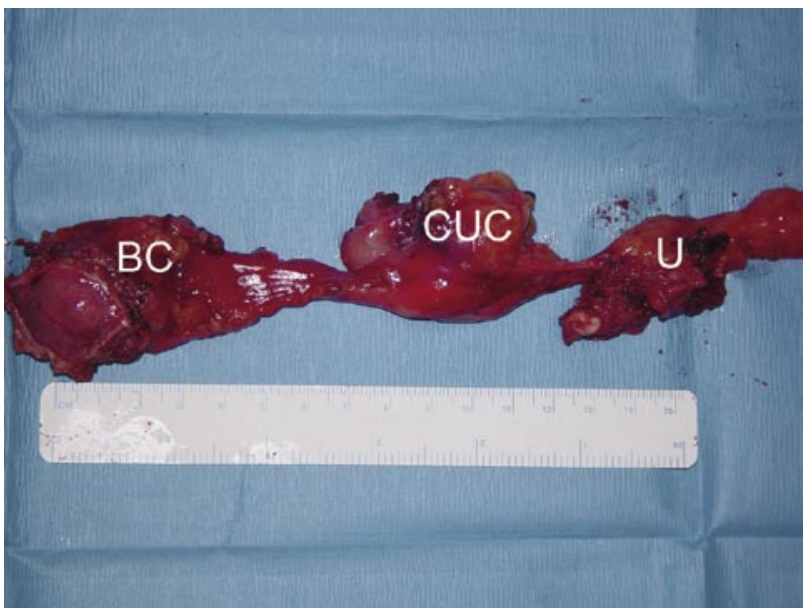

FIGURE 4. Partially calcified urachal cyst. The complete surgical specimen includes umbilicus $(U)$, calcified urachal cyst (CUC) and bladder cuff (BC). 


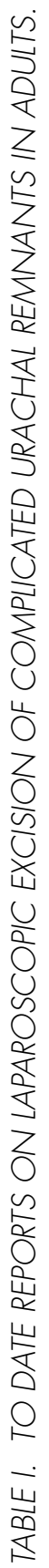

\begin{tabular}{|c|c|c|c|c|c|c|c|c|c|c|c|c|c|c|c|c|}
\hline$\frac{\text { 흠 }}{\text {. }}$ & $\begin{array}{l}\stackrel{0}{c} \\
\text { O } \\
Z\end{array}$ & & $\begin{array}{l}0 \\
\stackrel{0}{0} \\
Z\end{array}$ & & $\begin{array}{l}\stackrel{0}{c} \\
\stackrel{0}{Z}\end{array}$ & & $\begin{array}{l}\stackrel{0}{c} \\
\stackrel{0}{Z}\end{array}$ & & 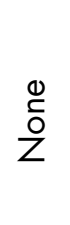 & & $\begin{array}{l}0 \\
\stackrel{0}{0} \\
Z\end{array}$ & & $\begin{array}{l}\stackrel{0}{0} \\
\stackrel{0}{Z}\end{array}$ & & $\begin{array}{l}\stackrel{0}{0} \\
\text { Z }\end{array}$ & \\
\hline$\frac{\text { 응 }}{\frac{0}{0}}$ & 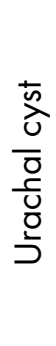 & & $\begin{array}{l}\bar{n} \\
\frac{\tilde{d}}{0} \\
\bar{\sigma} \\
\bar{d} \\
\overline{0} \\
\frac{0}{D}\end{array}$ & & 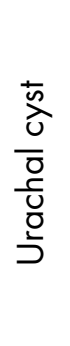 & & 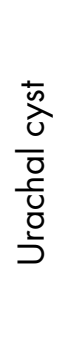 & & $\begin{array}{l}\bar{s} \\
\frac{\mathrm{J}}{0} \\
\overline{0} \\
\bar{U} \\
\frac{0}{D}\end{array}$ & & 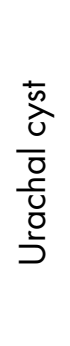 & & $\begin{array}{l}\frac{n}{2} \\
\frac{c}{n} \\
\frac{0}{0} \\
\frac{0}{0} \\
\frac{0}{D}\end{array}$ & & 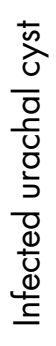 & 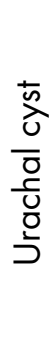 \\
\hline $\begin{array}{l}\text { ते } \\
\text { ब্ } \\
\text { 今 }\end{array}$ & 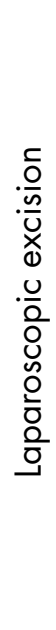 & 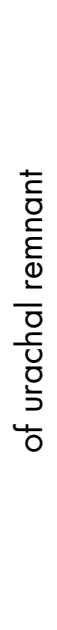 & 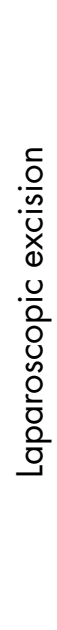 & 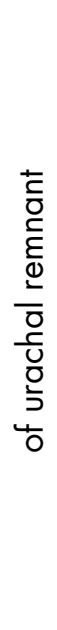 & 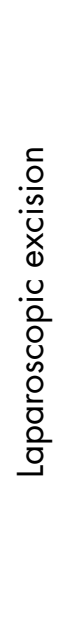 & 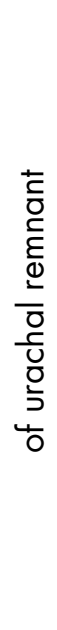 & 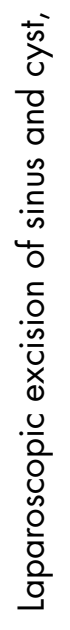 & 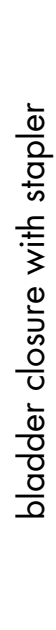 & 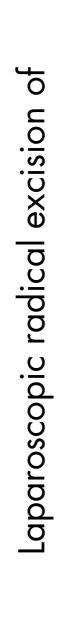 & 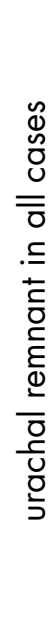 & 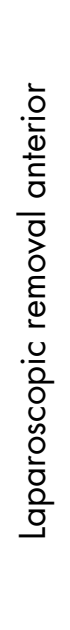 & 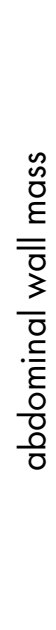 & 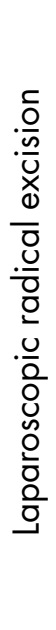 & 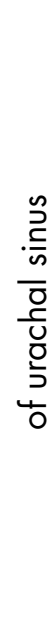 & 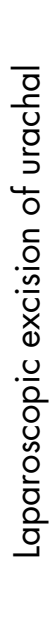 & 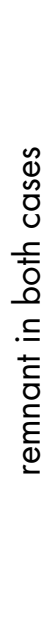 \\
\hline 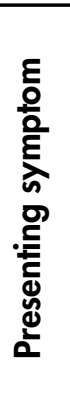 & 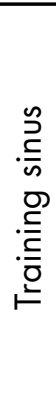 & 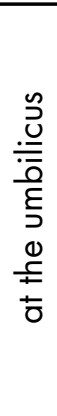 & 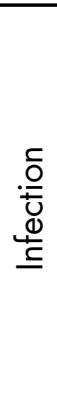 & & 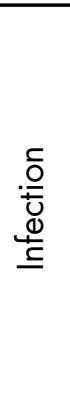 & & 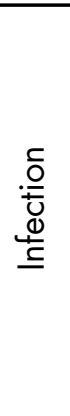 & & $\begin{array}{l}\frac{.0}{0} \\
\frac{0}{3} \\
\frac{0}{0} \\
\frac{0}{3} \\
0 \\
0 \\
0 \\
\frac{0}{4}\end{array}$ & 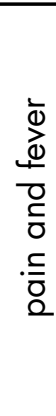 & 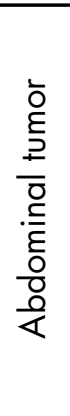 & & 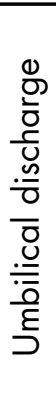 & & 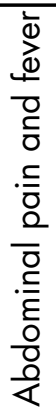 & 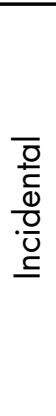 \\
\hline$\stackrel{8}{\stackrel{8}{4}}$ & $\stackrel{\infty}{\sim}$ & & $\stackrel{\infty}{-}$ & & ถે & & $\bar{\sim}$ & & $\stackrel{m}{\stackrel{m}{\sigma}}$ & $\begin{array}{l}\bar{\tau} \\
\bar{\delta} \\
\underline{\Phi}\end{array}$ & $\stackrel{\infty}{\sim}$ & & $\stackrel{0}{\circ}$ & & $\stackrel{\sim}{N}$ & $\stackrel{\infty}{m}$ \\
\hline હ & レ & & ᄂ & & ᄂ & & $\Sigma$ & & $\stackrel{4}{m}$ & $\Sigma$ & レ & & ч & & $\Sigma$ & $\Sigma$ \\
\hline$\frac{\text { ㅇ }}{\frac{7}{3}}$ & $\begin{array}{l}\vdash \\
\text { D } \\
\stackrel{c}{0} \\
+\frac{1}{3} \\
\dot{0} \\
Z\end{array}$ & $\stackrel{\curvearrowright}{\alpha}$ & $\frac{\text { 岁 }}{\stackrel{\Phi}{\Phi}}$ & 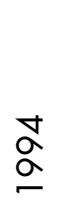 & 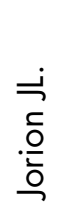 & ন & $\begin{array}{l}z \dot{Z} \\
0 \\
\stackrel{0}{0} \\
\dot{D}\end{array}$ & 음 & $\begin{array}{l}\dot{j} \\
\frac{0}{0} \\
\frac{d}{0} \\
\dot{0}\end{array}$ & 응 & 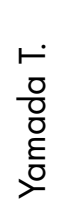 & চ্ণ & 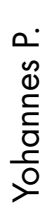 & ঙ্ণ & $\begin{array}{l}0 \\
0 \\
0 \\
\frac{0}{\bar{c}} \\
\dot{0} \\
\dot{U}\end{array}$ & ○ి \\
\hline
\end{tabular}


fasciitis which is a rare complication usually seen in children (7-9).

The presence of an urachal cyst must be always suspected when localized supra-pubic pain is associated with micturition disorders, even with sterile urine. Cases have been reported of patients with infected cysts which were mistakenly diagnosed as acute appendicitis, ovarian torsion or complicated Meckel's diverticulum (10).

The location of the urachus on the inferior abdominal wall makes diagnosis of the cyst easier by means of ultrasound and tomography (11). Computed tomography can ease diagnosis of urachal adenocarcinoma and also show specific characteristics associated with pyourachus (12).

Complicated urachal cysts usually warrant surgical treatment, but initially conservative management can be attempted (5). A 30\% of recurrence is seen when complicated urachal cysts are managed conservatively by means of drainage and antibiotic therapy (13). Therefore the treatment of choice is a complete excision of the lesion with a partial cystectomy of the bladder apex.

There have been few reports on laparoscopic excision of urachal abnormalities $(2,14-18)$. (Table I).

The scarce number of cases published and the absence of perioperative and convalescence data for incisional urachal surgery limit the comparison between the open and laparoscopic approaches. We believe that the outcomes described in this report may help favor the laparoscopic approach over the conventional incisional approach in the management of urachal pathology.

\section{CONCLUSIONS}

Clinical diagnosis and treatment of urachal pathology is often delayed due to non specific signs. The use of ultrasound and computed tomography is fundamental so as to obtain a prompt and precise diagnosis. The treatment of choice is the complete excision of the complicated lesion. For this matter laparoscopic surgery assures surgical results comparable to conventional surgery adding the advantages of a minimally invasive approach.

\section{REFERENCES AND RECOMENDED READINGS (*of special interest, ${ }^{* *}$ of outstanding interest)}

**1. MOORE, K.L.: “The developing Human”, 2nd Edition. Page 113, WB Saunders, Philadelphia, 1977.

2. CADEDDU, J.; BOYLE, K.; FABRIZIO, M. et al: "Laparoscopic management of urachal cysts in adulthood". J. Urol., 164: 1536, 2000.

**3. NAVARRETE, S.; SANCHEZ-ISMAYEL, A.; SANCHEZ-SALAS, R.E. et al: "Treatment of urachal anomalies: a minimally invasive surgery technique”. JSLS. Oct-Dec; 9:422, 2005.

*4. STERLING, J.A.: "Lesions of the urachus which appear in the adult". Ann. Surg., 137: 120, 1953.

5. BERMAN, S.M.; TOLIA, B.M. et al: "Urachal remnants in adults". Urology, 31: 17, 1988.

*6. MACNEILY, A.E.; KOLEILAT, N.; KIRIULUTA H.G. et al: "Urachal abscesses: protean manifestations, their recognition and management". Urology, 40: 530, 1992.

7. IUCHTMAN, M.; RAHAV, S.; ZER, M. et al: "Management of urachal anomalies in children and adults. Urology" 42: 426, 1993.

8. HORGAN, P.G.; JOHNSON,S.; COURTNEY, D.: "Intraperitoneal rupture of infected urachus". BJU Int, 73: 216, 1994.

9. O’CONNOR, J.; BIYANI, C.; AUSTIN, O. et al: "Necrotizing fasciitis: a rare complication of an infected urachal remnant in adults". J. Urol., 170: 920, 2003.

10. BLICHERT-TOFT, M.; NIELSEN, O.: "Congenital patent urachus and acquired variants". Act. Chir. Scand, 137: 807, 1971.

11. ROBERT, Y.; HENNQUIN, C.; CHAILLET D.: "Urachal remnants: sonographic assessment". J. Clin. Ultrasound, 24: 339, 1996.

12. HERMAN, T.E.; SCHACKELFORD, G.D.: "Pyourachus CT manifestations". J. Comput. Assist. Tomogr., 19: 440, 1995.

13. MARMOL, S.; GUADALAJARA, J.; CANCELO, P.: Quiste piouracal. Arch. Esp. Urol., 45: 1034, 1992.

*14. NEUFANG, T.; LUDTKE, F.E.: "Laparoscopic excision of an urachal fistula - new therapy for a rare disorder". Min Invasive Ther. 1:245, 1992.

*15. JORION, J.L.: "Laparoscopic removal of urachal cyst". J. Urol., 151: 1006, 1994.

16. SIEGEL, J.F.; WINFIELD, H.N.; VALDERRAMA, E.: Laparoscopic escisión of urachal cyst. J. Urol., 151: 1631, 1994.

**17. STONE, N.; GARDEN, R.; WEBER, H.: "Laparoscopic excision of an urachal cyst". Urology, 45: 161, 1995.

18. KHURANA, S.; BORZI, P.A.: "Laparoscopic management of complicated urachal disease in children". J. Urol., 168: 1526, 2002. 